\title{
The metabolism of glucose, acetate, palmitate, stearate and oleate in pigs
}

\author{
By C. P. FREEMAN, D. E. NOAKES AND E. F. ANNISON \\ Unilever Research Laboratory, Colworth House, Sharnbrook, Bedford
}

(Received 29 October 1969-Accepted 9 February 1970)

\begin{abstract}
1. Isotope dilution techniques were used to measure the rates of entry and oxidation of glucose, acetate, palmitate, stearate and oleate in fed and fasted ( $16 \mathrm{~h}$ ) pigs.

2. Glucose entry rates measured in eight fed and five fasted ( $16 \mathrm{~h}$ ) pigs were 20.6 and $8.0 \mathrm{mg} / \mathrm{min}$ per $\mathrm{kg}^{0.75}$ (mean values) respectively. The entry rates in fed pigs were lower than the calculated rates of glucose uptake from the alimentary tract, and the validity of glucose entry rates determined under these conditions is discussed.

3. Acetate entry rates were unrelated to the fibre content of the diet, and acetate produced from endogenous metabolism was the main contributor to total acetate production.

4. Increased rates of entry and oxidation of palmitate, stearate and oleate were observed in fasted pigs.

5. Glucose production in fasted pigs was inhibited by raising the concentration of blood glucose. Infusion of insulin in the fed pig caused a decrease in glucose production and a simultaneous reduction in the mobilization of free fatty acids. When blood glucose concentrations fell below about $55 \mathrm{mg} / 100 \mathrm{ml}$ the release of free fatty acid into the circulation was restored.
\end{abstract}

There have been few quantitative studies on glucose and fatty acid metabolism in pigs. Glucose tolerance tests in mature pigs gave results which closely resembled those obtained in man (Eveleth \& Eveleth, 1935; Hanawalt, Link \& Sampson, 1947), and the responsiveness of pigs to insulin was also similar to that shown by man (Sampson \& Graham, 1943). Acetate is normally present in the caecum and large intestine of pigs (Elsden, Hitchcock, Marshall \& Phillipson, 1945-6; Friend, Nicholson \& Cunningham, 1963), and the absorption of acetate from these sites was demonstrated by Barcroft, McAnally \& Phillipson (1944). Friend, Nicholson \& Cunningham (1964) compared acetate levels in arterial and portal blood samples from anaesthetized pigs, and concluded that acetate absorbed from the alimentary tract made a quantitatively significant contribution to the energy requirement of the pig. In the present studies we have used isotope dilution techniques to measure the rates of turn-over of glucose, acetate, palmitate, stearate and oleate in unanaesthetized fed and starved $(16 \mathrm{~h})$ pigs. The effects of raised blood concentrations of glucose on glucose production, and the effects of insulin on glucose and plasma free fatty acid (FFA) metabolism, were also studied.

\section{MATERIALS AND METHODS}

\section{Experimental animals}

Large White $\times$ Wessex pigs (6-12 weeks of age) were housed in metabolism crates in the laboratory. At least $3 \mathrm{~d}$ before an experiment polyethylene catheters (Portex Plastics Ltd, UK) were inserted under general anaesthesia into the external jugular vein $(1 \cdot 7 \mathrm{~mm}$ external diameter) and the carotid artery $(\mathrm{I} \cdot 52 \mathrm{~mm} \mathrm{ED})$ and in some cases 
the external thoracic vein $(1 \cdot 52 \mathrm{~mm} E D)$. The catheters were kept patent for periods of up to I month by twice-daily flushing with heparin-saline (2500 units $/ \mathrm{ml}$ ).

\section{Diet}

Pigs were normally fed $a d$ lib. on a pelleted diet ( $22 \%$ protein, $6.5 \%$ fat, $2 \%$ fibre). During some of the experiments, which are indicated below, the fibre content was increased to $5-6 \%$ by the addition of cellophane flake. Water was available at all times. Food and water intakes were recorded.

\section{Experimental procedure}

The intravenous infusions of isotopes were carried out in the animals' own crates, using procedures similar to those described earlier (Annison \& White, 196r). Rates of entry of substrate into the total body pool were calculated as described earlier (Annison $\&$ White, I962). In all experiments, unless otherwise indicated, the substrate was infused for a period of $4 \mathrm{~h}$, and blood samples were withdrawn during the final hour of the infusion. It was our experience that this period of infusion $(3 \mathrm{~h})$ was necessary for the specific radioactivity (sra) of the metabolites to reach constant levels; in those cases where the plasma levels or the sra of the metabolites varied by more than $\pm 10 \%$, the experiment was rejected. The sra of $\mathrm{CO}_{2}$ in arterial blood during the terminal stages of the infusion in relation to the sra of the infused metabolite provided a rough measure of the contribution of the substrate to total $\mathrm{CO}_{2}$ production (Annison, Brown, Leng, Lindsay \& West, 1967). Details of the infusions of the different substrates, and the methods of sampling are described below.

Metabolism of glucose. Uniformly labelled [ $\left.{ }^{14} \mathrm{C}\right]$ glucose in $0.9 \%$ (w/v) $\mathrm{NaCl}(0.3 \mu \mathrm{Ci}$; I $\mathrm{mg} / \mathrm{ml}$ ) was infused at $0.5 \mathrm{ml} / \mathrm{min}$ into the jugular vein immediately after a priming dose ( $15 \mu \mathrm{Ci}$ ) of labelled glucose. Blood samples $(8 \mathrm{ml})$ were withdrawn at $10 \mathrm{~min}$ intervals from the carotid artery during the last hour of the infusion. In three experiments the $\left[{ }^{14} \mathrm{C}\right]$ glucose was infused into the external thoracic vein and five pairs of samples of carotid and jugular blood were taken simultaneously. In one experiment to examine the effect of glucose load on glucose metabolism, unlabelled glucose was infused with labelled glucose at rates varying from 50 to $200 \mathrm{mg} / \mathrm{min}$.

Metabolism of acetate. Sodium[1,2-14 C]acetate in $0.9 \%(\mathrm{w} / \mathrm{v}) \mathrm{NaCl}$ was infused $(0.5 \mu \mathrm{Ci} ; \mathrm{r} \mathrm{mg} / \mathrm{min})$ into the jugular vein without a priming dose. Blood samples ( $10 \mathrm{ml}$ ) were withdrawn from the carotid artery as described above.

Metabolism of plasma palmitate, stearate and oleate. $\left[\mathrm{U}-{ }^{14} \mathrm{C}\right]$ palmitic, $\left[\mathrm{U}-{ }^{14} \mathrm{C}\right]$ stearic or $\left[\mathrm{U}-{ }^{14} \mathrm{C}\right]$ oleic acid, and $\left[9,10-{ }^{3} \mathrm{H}\right]$ palmitic acid were infused as aqueous solutions of their sodium salts in albumin, prepared as described by Laurell (1957), at the rate of $0.25 \mu \mathrm{Ci} / \mathrm{min}$ (except $\left[9,10-{ }^{3} \mathrm{H}\right]$ palmitate; see below) into the jugular vein. Albumin (bovine serum albumin, fraction $\mathrm{V}$ powder), obtained from Sigma Chemical Co. (London) Ltd, was used. Arterial blood samples (Io ml) were taken as described above. 


\section{Effect of insulin on the metabolism of glucose and palmitate}

$\left[\mathrm{U}-{ }^{14} \mathrm{C}\right]$ glucose and $\left[9, \mathrm{ro}^{3} \mathrm{H}\right]$ palmitate were simultaneously infused into the jugular vein of a fed pig $(29 \mathrm{~kg})$ at the rate of $0 \cdot 257 \mu \mathrm{Ci}$ and $\mathrm{I} \cdot 420 \mu \mathrm{Ci} / \mathrm{min}$ respectively, with a priming dose of $25 \mu \mathrm{Ci}$ of $\left[\mathrm{U}_{-}{ }^{14} \mathrm{C}\right]$ glucose given prior to the start of the infusion. From the 26oth min of the infusion, insulin (Insulin BP; Boots Pure Drug Co. Ltd) was infused into the external thoracic vein at the rate of $2 \mathrm{~m}$-units/min per $\mathrm{kg}$ bodyweight, and was stopped $120 \mathrm{~min}$ later. The dual isotope infusion continued for $415 \mathrm{~min}$.

\section{Radioactive materials}

Labelled compounds were obtained from the Radiochemical Centre, Amersham.

\section{Chemical methods}

Plasma glucose sra. Plasma glucose concentrations were measured with glucose oxidase (Huggett \& Nixon, 1957). Glucose was isolated as the pentaacetate (Jones, 1965) after purification with ion-exchange resins. Preliminary work showed that labelled acetate and labelled lactate may both contaminate glucose pentaacetate if present in the reaction mixture. Plasma ( $\mathrm{r} \mathrm{ml}$ ) containing carrier glucose $\left(\mathrm{r}_{5} \mathrm{O} \mathrm{mg}\right.$ ) was deproteinized by adding $\mathrm{H}_{2} \mathrm{O}(4 \mathrm{ml}), 0.3 \mathrm{~N}-\mathrm{Ba}(\mathrm{OH})_{2}(2 \mathrm{ml})$ and, after shaking, $2 \mathrm{ml}$ of $\mathrm{ZnSO}_{4} \cdot 7 \mathrm{H}_{2} \mathrm{O}(5 \% \mathrm{w} / \mathrm{v})$. The filtrate was passed through a column (diam. $\mathrm{I} \cdot 5 \mathrm{~cm}$ ) of a mixed bed of Amberlite (British Drug Houses Ltd) ion-exchange resins (IRC 50 and $\mathrm{IR}_{45}, 2: \mathrm{I}, \mathrm{v} / \mathrm{v}$ ), and the glucose eluted with $100 \mathrm{ml}$ of deionized water. The eluate was concentrated in vacuo before preparation of the pentaacetate, which was assayed for radioactivity as described below.

Blood acetate sra. The concentration of acetate in blood was measured by gas-liquid chromatography, using an internal standard. Sodium propionate $(100 \mu \mathrm{g})$ was added to blood $(5 \mathrm{ml})$ and the total volatile fatty acids (VFA) were isolated by deproteinization and steam distillation as described earlier (Annison \& White, 1962). The neutralized distillate, containing $50 \%$ excess $\mathrm{NaOH}$, was concentrated to $2-3 \mathrm{ml}$ by boiling. A sample (ro \%) was dried down, the sodium salts were dissolved in roo $\mu$ l of $5 \%$ orthophosphoric acid, and I-5 $\mu \mathrm{l}$ were transferred to a Model I04 gas chromatograph (Pye Unicam Ltd, Cambridge) fitted with a flame ionization detector. The stationary phase was acid-washed Chromosorb W coated with $10 \%(\mathrm{w} / \mathrm{w})$ neo-pentyl glycol adipate (Pye Ltd, Cambridge), and the operating temperature was $125^{\circ}$, with nitrogen as carrier gas. The relative areas of the acetate and propionate peaks (corrected for detector response) allowed calculation of the concentration of acetate in the original blood sample.

The remainder of the VFA sample was assayed for radioactivity as described below.

Blood lactate sra. Blood lactate concentrations were measured enzymically (Barker \& Britton, 1957). Lactate was isolated from blood $(5 \mathrm{ml})$ as described earlier (Annison, Lindsay \& White, 1963 ), using $100 \mathrm{mg}$ of lithium lactate as carrier. The isolated zinc lactate was assayed for radioactivity as described below.

Plasma free fatty acids ( $F F A$ ) sra. Plasma lipids were extracted by the method of Folch, Lees \& Stanley (1957), and an internal standard, heptadecanoic acid, was 
added to the extract in the proportion $20 \mu \mathrm{g} / \mathrm{ml}$ plasma. The FFA fraction was isolated by thin-layer chromatography on silica gel in the system diethyl ether-hexane-acetic acid $(30: 70: 2, v / v)$ and eluted from the silica with $15 \mathrm{ml}$ of diethyl ether-light petroleum (b.p. 40-60 )-formic acid $(50: 50: 1, v / v)$. The concentration of individual fatty acids in the FFA fraction was determined by gas-liquid chromatography using the method described by West $\&$ Rowbotham (1967). A portion of the separated FFA fraction was assayed for radioactivity as described below.

Blood carbon dioxide sra. Blood $\mathrm{CO}_{2}$ was isolated as described by Annison \& Lindsay (1961) and assayed for radioactivity as described below.

Assay of radioactivity. All substrates were assayed by liquid scintillation counting using a Packard 4000 Series Spectrometer. Corrections for quenching were made using an external standard of ${ }^{226} \mathrm{Ra}$. Fatty acids and glucose pentaacetate were assayed in solution in toluene containing $0.4 \%, 2,4$-diphenyloxazole (PPO). Finely divided $\mathrm{BaCO}_{3}$ and zinc lactate were assayed in suspension in a gel of low-density silica (Cab-O-Sil; Packard Co., Wembley, Middlesex) $3.4 \% \mathrm{w} / \mathrm{v}$, in toluene containing $0.4 \%$ PPO. Acetate samples were dissolved in water $(\mathrm{I} \mathrm{ml})$ and mixed with $15 \mathrm{ml}$ of a mixture $(2: 1, v / v)$ of toluene containing $0.4 \% \mathrm{PPO}$ and a non-ionic detergent (Triton-X-Ioo; Lennig Chemical Co., Jarrow-on-Tyne) which gave a one-phase system suitable for counting.

\section{RESULTS}

\section{Equilibrium of bicarbonate pools}

The sra of arterial blood $\mathrm{CO}_{2}$ during the infusion of ${ }^{14} \mathrm{C}$-labelled glucose or acetate

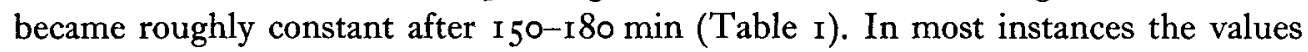
rose by $5-10 \%$ during the period $180-240 \mathrm{~min}$, but insufficient values were obtained to allow calculation of a terminal asymptotic value (Annison et al. 1967).

\section{Metabolism of glucose}

Mean arterial plasma glucose levels in seven fed and six fasted ( $16 \mathrm{~h}$ ) pigs were II I (range IOI-I I9) and $96(87-1 \mathrm{IO}) \mathrm{mg} / \mathrm{IO0} \mathrm{ml}$ respectively (Table 2). In three experiments the mean arteriovenous differences in plasma glucose across the head were 9,7 and $5 \mathrm{mg} / \mathrm{roo} \mathrm{ml}$. The oxidation of glucose by the tissues of the head was indicated by the increased specific radioactivity of jugular blood ${ }^{14} \mathrm{CO}_{2}$ relative to arterial ${ }^{14} \mathrm{CO}_{2}$ (Table I).

Glucose entry rates measured in seven fed and six fasted ( $16 \mathrm{~h}$ ) pigs were 20.6 (SE I.4I) and 8.0 (SE 0.59) $\mathrm{mg} / \mathrm{min}$ per $\mathrm{kg}^{0.75}$ respectively (Table 2 ). The mean value in fed pigs was considerably lower than the rate of uptake of glucose from the alimentary tract $\left(26-32 \mathrm{mg} / \mathrm{min}\right.$ per $\left.\mathrm{kg}^{0.75}\right)$ calculated from the known intakes of starch, sucrose and lactose. The rates of intake of the glucose sources were based on the mean daily consumption of food recorded over a period of about $7 \mathrm{~d}$ prior to the infusion. In estimating the uptake of glucose, complete hydrolysis and absorption were assumed and galactose and fructose derived from lactose and sucrose respectively were calculated as glucose. 
Vol. 24

The contributions of glucose to total $\mathrm{CO}_{2}$ production were $3 \mathrm{I} \%$ (SE 5.7 ) and $16 \%$ (SE $\mathrm{I} \cdot 9$ ) respectively in fed and starved pigs (Table 2 ).

Table 1. Changes in the specific radioactivity of ${ }^{14} \mathrm{CO}_{2}$ and the glucose concentrations in carotid and jugular blood during the infusion of $\left[U-{ }^{14} C\right]$ glucose

('The values are the results of a typical experiment on one pig)

\begin{tabular}{|c|c|c|c|c|}
\hline \multirow[b]{2}{*}{ Time (min) } & \multicolumn{2}{|c|}{$\begin{array}{l}\text { Plasma glucose } \\
\text { (mg/roo ml) }\end{array}$} & \multicolumn{2}{|c|}{$\begin{array}{l}\text { Specific radioactivity of } \\
\text { blood }{ }^{14} \mathrm{CO}_{2}(\mu \mathrm{Ci} / \mathrm{g} \mathrm{C})\end{array}$} \\
\hline & Carotid & Jugular & Carotid & Jugular \\
\hline 60 & - & - & $I \cdot 85$ & - \\
\hline I 20 & - & 一 & I. 85 & - \\
\hline 140 & - & - & 2.30 & - \\
\hline 160 & - & - & $2 \cdot 36$ & - \\
\hline 180 & $9^{8}$ & 94 & $2 \cdot 38$ & $2 \cdot 40$ \\
\hline I95 & 103 & 96 & $2 \cdot 33$ & $2 \cdot 45$ \\
\hline 210 & 103 & 98 & $2 \cdot 30$ & $2: 40$ \\
\hline 225 & 102 & 95 & $2 \cdot 32$ & $2 \cdot 39$ \\
\hline 240 & IOI & 96 & $2 \cdot 39$ & - \\
\hline
\end{tabular}

Table 2. Levels of plasma glucose, rates of entry of glucose, and the contribution of glucose to total $\mathrm{CO}_{2}$ production in fed and fasted ( $16 h$ ) pigs

\begin{tabular}{|c|c|c|c|}
\hline Nutritional status & $\begin{array}{c}\text { Plasma } \\
\text { glucose } \\
(\mathrm{mg} / 100 \mathrm{ml})\end{array}$ & $\begin{array}{c}\text { Entry rate } \\
\left(\mathrm{mg} / \mathrm{min} \mathrm{kg}^{0 \cdot 75}\right)\end{array}$ & $\begin{array}{c}\text { Contribution } \\
\text { to total } \mathrm{CO}_{2} \\
\text { output }(\%)\end{array}$ \\
\hline \multirow[t]{7}{*}{ Fed } & 112 & $22 \cdot 0$ & 49 \\
\hline & 119 & 16.9 & $4 \mathrm{I}$ \\
\hline & 105 & $19^{\circ} \mathrm{I}$ & 25 \\
\hline & 101 & $22 \cdot 8$ & 12 \\
\hline & I I 5 & $22 \cdot 0$ & 20 \\
\hline & I I 5 & $26 \cdot 0$ & 37 \\
\hline & I 10 & $15 \cdot 2$ & 一 \\
\hline General mean $\pm \mathrm{SE}$ & I II $\pm 2 \cdot 36$ & $20 \cdot 6 \pm I \cdot 4 I$ & $3 I \pm 5 \cdot 7$ \\
\hline \multirow[t]{5}{*}{ Fasted } & 100 & $5 \cdot 6$ & 16 \\
\hline & $\begin{array}{l}97 \\
96\end{array}$ & $\begin{array}{l}9.5 \\
8.6\end{array}$ & $\begin{array}{l}17 \\
24\end{array}$ \\
\hline & 87 & $7 \cdot 0$ & II \\
\hline & IIO & $8 \cdot 6$ & I 8 \\
\hline & 89 & $8 \cdot 8$ & 12 \\
\hline General mean $\pm \mathrm{SE}$ & $96 \pm 3.69$ & $8 \cdot 0 \pm 0.59$ & $I 6 \pm I \cdot 9$ \\
\hline
\end{tabular}

Glucose entry rates were correlated with plasma level $(r=0.67 \mathrm{I} ; P<0.02)$ and the contribution of glucose to total $\mathrm{CO}_{2}$ production showed some dependence on substrate concentration $(r=0.719 ; P<0.01)$.

\section{Effect of glucose load}

When unlabelled glucose was infused with labelled glucose at a rate $(200 \mathrm{mg} / \mathrm{min})$ sufficient to raise the circulating level of glucose to $140-15^{\circ} \mathrm{mg} / 100 \mathrm{ml}$ in the starved $(24 \mathrm{~h}) \mathrm{pig}$, glucose production was completely inhibited (Table 3 ). At lower plasma 
concentrations ( $120-150 \mathrm{mg} / \mathrm{I} 00 \mathrm{ml}$ ) achieved by infusing glucose at $50-150 \mathrm{mg} / \mathrm{min}$, partial inhibition was indicated by the low entry rates obtained, after correction for the input of carrier glucose.

\section{Metabolism of acetate}

Mean arterial blood levels of acetate in fourteen fed and four fasted pigs were 2.5 (SEO IO) and $2 \cdot 2\left(\mathrm{SEO} \cdot \mathrm{I}_{3}\right) \mathrm{mg} / \mathrm{IOO} \mathrm{ml}$ respectively. The mean rates of entry of acetate in six fed and four fasted pigs were $\mathrm{r} \cdot .8$ and $9.2 \mathrm{mg} / \mathrm{min}$ per $\mathrm{kg}^{0.75}$ respectively, and

Table 3. Inhibition of entry of endogenous glucose at raised concentrations of plasma glucose in the pig

$\begin{array}{ccccc}\text { Plasma } & \begin{array}{c}\text { Rate of } \\ \text { infusion of } \\ \text { unlabelled } \\ \text { glucose } \\ (\mathrm{mg} / \mathrm{min})\end{array} & \begin{array}{c}\text { Total entry } \\ \text { rate of } \\ \text { glucose }(\mathrm{B}) \\ (\mathrm{mg} / \mathrm{min})\end{array} & \begin{array}{c}\text { Entry rate } \\ \text { of endogenous } \\ \text { glucose } \\ (\mathbf{B}-\mathrm{A})\end{array} \\ (\mathrm{mg} / \mathrm{min}) \\ \text { I } & \mathrm{mg} / \mathrm{ro0} \mathrm{ml}) & 50 & & 79 \\ 2 & 120 & 100 & 129 & 51 \\ 3 & 126 & 150 & 151 & 23 \\ 4 & 136 & 200 & 204 & 4 \\ 5 & 141 & 200 & 207 & 7\end{array}$

Table 4. Levels of blood acetate, rates of entry of acetate, and the contribution of acetate to total $\mathrm{CO}_{2}$ production, in fed and fasted ( $\left.\mathrm{I}_{6} 6 \mathrm{~h}\right)$ pigs given low-fibre $(L)$ and high-fibre $(H)$ diets

\begin{tabular}{|c|c|c|c|c|}
\hline Nutritional status & $\begin{array}{l}\text { Level of } \\
\text { dietary fibre }\end{array}$ & $\begin{array}{c}\text { Blood } \\
\text { acetate } \\
(\mathrm{mg} / \mathrm{roo} \mathrm{ml})\end{array}$ & $\begin{array}{c}\text { Entry rate } \\
\left(\mathrm{mg} / \mathrm{min} \mathrm{kg}^{0 \cdot 75}\right)\end{array}$ & $\begin{array}{l}\text { Contribution } \\
\text { to total } \mathrm{CO}_{2} \\
\text { output }(\%)\end{array}$ \\
\hline \multirow[t]{6}{*}{ Fed } & $\mathbf{L}$ & $2 \cdot 5$ & $12 \cdot I$ & 12 \\
\hline & $\mathrm{L}$ & $2 \cdot 2$ & II $x \cdot 9$ & 12 \\
\hline & $\mathbf{L}$ & $2 \cdot 4$ & $8 \cdot 1$ & 9 \\
\hline & $\mathrm{H}$ & $2 \cdot \dot{8}$ & $12 \cdot 9$ & Io \\
\hline & $\mathrm{H}$ & $2 \cdot 3$ & $I I \cdot I$ & Io \\
\hline & $\mathrm{H}$ & $2 \cdot 5$ & $14 \cdot 6$ & 18 \\
\hline General mean $\pm \mathrm{SE}$ & & $2 \cdot 5 \pm 0 \cdot 10$ & II $\cdot 8 \pm 0.88$ & $12 \pm 1 \cdot 46$ \\
\hline Fasted & $\mathbf{L}$ & $2 \cdot 4$ & $8 \cdot 8$ & 22 \\
\hline & $\mathrm{H}$ & $1 \cdot 9$ & $8 \cdot 2$ & I 8 \\
\hline & $\mathrm{H}$ & $2 \cdot 1$ & II $\cdot 0$ & 24 \\
\hline & $\mathrm{H}$ & $2 \cdot 3$ & $8 \cdot 7$ & 22 \\
\hline General mean $\pm S E$ & & $2 \cdot 2 \pm 0 \cdot 13$ & $9 \cdot 2 \pm 0.71$ & $2 I \pm I \cdot 49$ \\
\hline
\end{tabular}

corresponding values for the contribution of acetate to total $\mathrm{CO}_{2}$ output were about I2 $\%$ and $21 \%$ (Table 4 ).

The fibre content of the diets had no influence on either the concentrations of blood acetate, or the measured entry rates of acetate.

\section{Metabolism of plasma palmitate, stearate and oleate}

The composition of the plasma FFA fraction and the concentrations of individual plasma FFA were collated from the many analyses made during the course of experiments on a total of nine experimental animals, which were either fed or fasted 
(Table 5). There were significant shifts in the composition of the plasma FFA on fasting, the proportion of fatty acids $\left(\mathrm{C}_{12}, \mathrm{C}_{14}, \mathrm{C}_{15}\right)$ of medium chain length and of linoleate $(\mathrm{I} 8: 2)$ decreasing and the proportion of oleate (I8:I) increasing markedly. Although in general the levels of individual FFA were higher in fasted than in fed pigs, the variability in absolute concentrations between animals was large and for any fatty acid the difference between the mean concentration in fed and fasted pigs was not statistically significant.

Table 5. Fatty acid composition (major components as percentage by weight of the total) of plasma free fatty acids, and plasma levels of individual fatty acids in fed and fasted ( 16 h) pigs

(Values for composition are means and standard deviations; values for concentration are means with their ranges)

\begin{tabular}{|c|c|c|c|c|}
\hline \multirow[b]{2}{*}{$\begin{array}{l}\text { Fatty } \\
\text { acid }\end{array}$} & \multicolumn{2}{|r|}{ are means } & \multicolumn{2}{|c|}{ Fasted } \\
\hline & Composition (\%) & $\begin{array}{l}\text { Concentration } \\
(\mathrm{mg} / \mathrm{ro0} \mathrm{ml})\end{array}$ & Composition (\%) & $\begin{array}{l}\text { Concentration } \\
(\mathrm{mg} / \mathrm{r} 00 \mathrm{ml})\end{array}$ \\
\hline I2:0 & $2 \cdot 14 \pm 0.67$ & $0.30(0.24-0.42)$ & $0.61 \pm 0.29$ & $0.34(0.09-0.94)$ \\
\hline I4:0 & $3 \cdot 43 \pm I \cdot 34$ & $0.31(0.16-0.60)$ & $I \cdot 72 \pm 0.44$ & $0.58(0 \cdot 19-\mathrm{I} \cdot 45)$ \\
\hline $15: 0$ & $2 \cdot 27 \pm 1 \cdot 22$ & $0.21(0.08-0.39)$ & $I .0 I \pm 0.6 I$ & $0.38(0.09-0.93)$ \\
\hline I6:0 & $27 \cdot 91 \pm 5.57$ & $2 \cdot 26(1 \cdot 26-3 \cdot 80)$ & $26 \cdot 28 \pm 7 \cdot 3^{8}$ & $8.25(3.07-16.62)$ \\
\hline I6:I & $3 \cdot 92 \pm 1.05$ & $0.45(0.18-0.95)$ & $4.37 \pm 1.00$ & $I .36(0.6 I-3.6 I)$ \\
\hline $18: 0$ & $17.67 \pm 5.63$ & $I \cdot 33(0.83-2.25)$ & I $7 \cdot 85 \pm 5 \cdot 82$ & $5.88(2.52-13 \cdot 60)$ \\
\hline I 8: 1 & $28 \cdot 18 \pm 7 \cdot 57$ & $2 \cdot 6$ I (I.II-8.14) & $4 I \cdot 2 I \pm 4 \cdot 09$ & I $4.00(5.44-28 \cdot 49)$ \\
\hline $18: 2$ & $15.01 \pm 6.96$ & $1 \cdot 53(0.47-3.00)$ & $8 \cdot 54 \pm 2 \cdot 89$ & $3.00(0.81-11.03)$ \\
\hline
\end{tabular}

The above analyses showed that about $75 \%$ of pig plasma FFA was accounted for by palmitate, stearate and oleate. Mean values obtained for the rates of entry and oxidation of these individual fatty acids are shown in Table 6. Although there were insufficient observations for possible correlations between the plasma levels of the individual fatty acids and rates of entry and oxidation to be statistically examined, and in spite of the considerable variability of the results it seems likely that, on fasting, there was an increased rate of entry of palmitate, stearate and oleate and a greater contribution of these acids to total $\mathrm{CO}_{2}$ production.

\section{Effect of insulin}

The effect of insulin on the metabolism of glucose and of palmitate was studied using the double isotope technique. The concentrations and specific radioactivities of glucose and of palmitate during the experiment are shown in Fig. I. The sra of glucose declined more slowly than glucose concentration commencing from about $40 \mathrm{~min}$ from the infusion of insulin. Palmitate concentration decreased concomitantly with that of glucose accompanied by an increase in palmitate sra, indicating a depression in FFA release. When the glucose concentration fell below about $55 \mathrm{mg} / \mathrm{ro0} \mathrm{ml}$, i.e. after about $40 \mathrm{~min}$ of insulin infusion, the plasma concentration of palmitate increased and its sra decreased as FFA was released into the circulation. The concentrations of both palmitate and glucose rapidly returned to their pre-infusion levels when the infusion of insulin was terminated. 
Table 6. Rates of entry of palmitate, stearate and oleate, and their contribution to total $\mathrm{CO}_{2}$ production in fed and fasted ( 16 h) pigs

\begin{tabular}{|c|c|c|c|c|c|}
\hline Substrate & $\begin{array}{c}\text { Nutritional } \\
\text { status }\end{array}$ & $\begin{array}{c}\text { Plasma } \\
\text { level } \\
(\mathrm{mg} / 100 \mathrm{ml})\end{array}$ & $\begin{array}{c}\text { Total } \\
\text { plasma } \\
\text { FFA } \\
(\mathrm{mg} / \mathrm{r} \circ 0 \mathrm{ml})\end{array}$ & $\begin{array}{l}\text { Entry } \\
\text { rate } \\
(\mathrm{mg} / \mathrm{min} \\
\left.\mathrm{kg}^{0 \cdot 75}\right)\end{array}$ & $\begin{array}{l}\text { Approximate } \\
\text { contribution } \\
\text { to } \mathrm{CO}_{2}(\%)\end{array}$ \\
\hline \multirow{6}{*}[\mathrm{U}-{}^{14}\mathrm{C}]{ palmitate } & \multirow{3}{*}{ Fed } & $8 \cdot 0$ & $26 \cdot I$ & $12 \cdot 0$ & 6 \\
\hline & & $2 \cdot 9$ & $12 \cdot 1$ & $3 \cdot 3$ & 4 \\
\hline & & $\ln 3$ & 4.0 & $\mathbf{I} \cdot 3$ & $\mathbf{I}$ \\
\hline & \multirow{3}{*}{ Fasted } & $\int 14 \cdot 3$ & $58 \cdot 7$ & $12 \cdot 0$ & 24 \\
\hline & & $7 \bullet 4$ & $27 \cdot 8$ & $3 \cdot 0$ & 8 \\
\hline & & $(3.9$ & 14.9 & $1 \cdot 0$ & 6 \\
\hline \multirow{6}{*}[\mathrm{U}-{}^{14}\mathrm{C}]{ stearate } & \multirow{3}{*}{ Fed } & $(1 \cdot 2$ & $9 \cdot 2$ & $1 \cdot 3$ & $<\mathbf{I}$ \\
\hline & & $\{\cdot 9$ & $17 \cdot 2$ & $\mathbf{I} 3$ & $\mathbf{I}$ \\
\hline & & $2 \cdot 1$ & $7 \cdot 7$ & $1 \cdot 5$ & $<\mathrm{I}$ \\
\hline & \multirow{3}{*}{ Fasted } & $\left(5^{\cdot 6}\right.$ & $24 \cdot 3$ & $2 \cdot 9$ & 5 \\
\hline & & $\{9 \cdot 9$ & $67 \cdot 1$ & $4 \cdot 7$ & II \\
\hline & & $l_{3} \cdot 8$ & $21 \cdot 3$ & $1 \cdot 7$ & 6 \\
\hline \multirow{5}{*}[\mathrm{U}-{}^{14}\mathrm{C}]{ oleate } & \multirow{2}{*}{ Fed } & $\{I \cdot I$ & $5 \cdot 3$ & $I \cdot I$ & 3 \\
\hline & & $\{0.5$ & $2 \cdot 9$ & 0.6 & I \\
\hline & \multirow{3}{*}{ Fasted } & $7 \cdot 0$ & $15 \cdot 5$ & $3 \cdot 0$ & I 3 \\
\hline & & $\{.5$ & $12 \cdot 1$ & $3 \cdot 4$ & I I \\
\hline & & $6 \cdot 5$ & $17 \cdot 0$ & $1 \cdot 5$ & I 3 \\
\hline
\end{tabular}

Cross-labelling of glucose and acetate

In four experiments in which $\left[\mathrm{U}-{ }^{14} \mathrm{C}\right]$ glucose was infused into two fed and two fasted $(\mathrm{I} 6 \mathrm{~h}$ ) pigs, arterial blood samples were taken during the final stages of the infusions (after 220-240 min) and assayed for acetate. Comparison of the specific radioactivities of glucose and acetate showed that the acetate values were 12 and $15 \%$ (fed pigs) and 13 and $19 \%$ (fasted pigs) of those of glucose. In similar experiments in which the specific radioactivity of glucose was measured just before the completion of $\left[1,2-{ }^{14} \mathrm{C}\right]$ acetate infusions, the values for glucose were 4 and $7 \%$ (fed pigs), and 6 and $8 \%$ (fasted pigs) of the specific radioactivity of blood acetate.

\section{Transfer of radioactivity to lactate during labelled glucose infusions}

In four experiments the sra of blood lactate at the end of the $\left[\mathrm{U}-{ }^{14} \mathrm{C}\right]$ glucose infusions $(240 \mathrm{~min}$ ) were 20 and $47 \%$ (fed pigs) and 23 and $42 \%$ (fasted pigs), of those of blood glucose.

\section{DISCUSSION}

The use of isotope dilution techniques to obtain quantitative values for the metabolism of individual substrates in whole animals is well established, but previous work on the pig has been confined to studies on the metabolism of ${ }^{14} \mathrm{C}$-labelled glucose and acetate in the lactating sow (Gutte, Kleiber, Raggi \& Black, r96r; Linzell, Mepham, Annison \& West, r969), and of ${ }^{14} \mathrm{C}$-labelled glucose, palmitate and valine in growing pigs (Cunningham, 1967). Blood concentrations of acetate in fed and fasted pigs were 


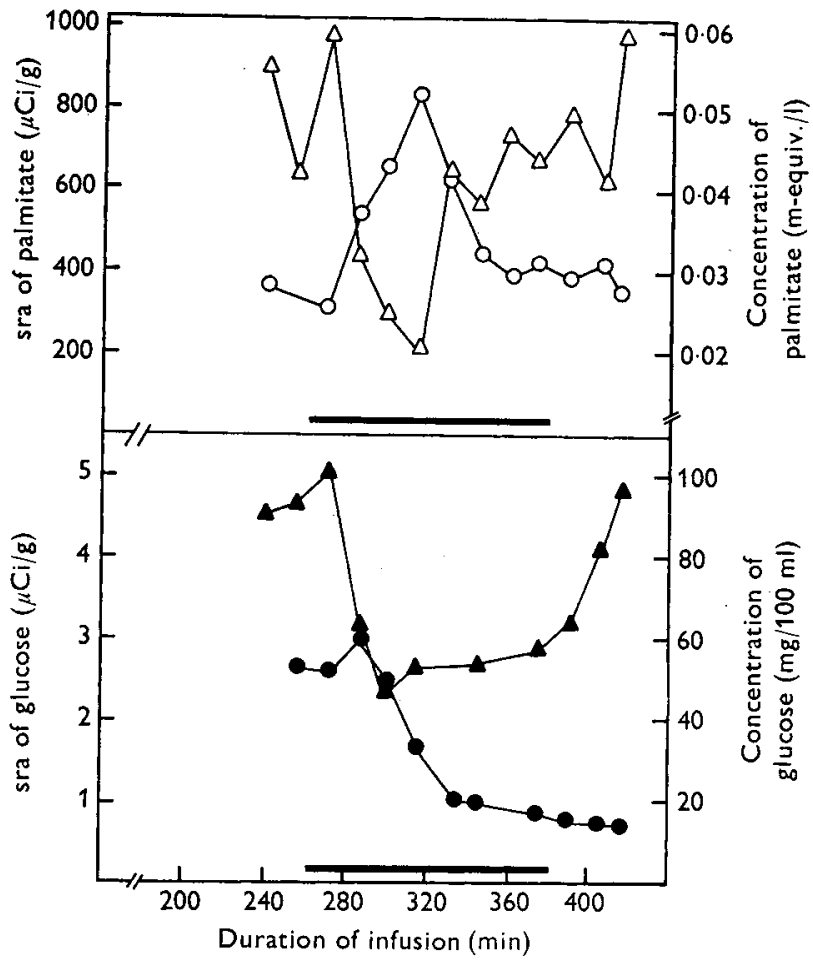

Fig I. Effect, in pigs, of a constant infusion of insulin on the specific radioactivity (sra) and concentrations of plasma glucose and palmitate during the continuous infusion of $\left[\mathrm{U}-{ }^{14} \mathrm{C}\right]$ glucose and $\left[9,10-{ }^{3} \mathrm{H}\right]$ palmitate. $O$, sra of palmitate $(\mu \mathrm{Ci} / \mathrm{g}) ; \Delta$, concentration of palmitate (m-equiv./1); - sra of glucose $(\mu \mathrm{Ci} / \mathrm{g}) ; \Delta$, concentration of glucose $(\mathrm{mg} / 100 \mathrm{ml})$. The infusion rates were $0.257 \mu \mathrm{Ci}$ of $\left[\mathrm{U}-{ }^{14} \mathrm{C}\right]$ glucose and $\mathrm{I} \cdot 420 \mu \mathrm{Ci}$ of $\left[9,10-{ }^{3} \mathrm{H}\right]$ palmitate/min with a priming dose of $25 \mu \mathrm{Ci}$ of $\left[\mathrm{U}-^{14} \mathrm{C}\right]$ glucose. Insulin was infused from 260 to $380 \mathrm{~min}$ (horizontal bar) at a rate of $2 \mathrm{~m}$-units/min per $\mathrm{kg}$ body-weight.

not substantially different, suggesting that acetate produced from endogenous metabolism is quantitatively of more significance than acetate absorbed from the alimentary tract. Acetate is produced in the gut largely by the caecal fermentation of cellulose residues, but in the young pigs used in the present studies the level of fibre in the ration had no influence on blood acetate levels, or on acetate entry rates. The role of endogenous acetate in mammalian metabolism is obscure (see Annison, 1964), but the high acetate entry rates observed in the present studies, and the substantial contribution of acetate to total $\mathrm{CO}_{2}$ production indicates that much of the acetyl CoA produced during metabolism must equilibrate with free acetate in blood. The equilibration of considerable acetyl CoA produced from glucose with blood acetate was shown by the transfer of radioactivity from glucose to acetate. The increased contribution of acetate to total $\mathrm{CO}_{2}$ production in the fasted pig probably reflects the increased oxidative metabolism of fatty acids mobilized from adipose tissue.

Plasma FFA metabolism in pigs closely resembles that of other mammalian species (see Annison, 1964). Plasma levels rise during fasting (Cunningham \& Friend, I965), reflecting mobilization of adipose tissue, and the increased entry of palmitate, stearate 
and oleate into body pools, and the increased contribution of these acids to oxidative metabolism in the fasted animal, are clearly shown in the present work. The plasma levels of FFA in fed and fasted pigs suggest a preferential mobilization of oleic acid on fasting, but this is not reflected in the relative increase in the entry into the plasma pool of oleate compared to palmitate and stearate. The disproportionate change in circulating levels of the medium-chain fatty acids and linoleate on fasting suggests that these acids are oxidatively metabolized to a larger extent than other fatty acids, but their quantitative significance is small relative to palmitate, stearate and oleate.

The effects of insulin on plasma FFA and glucose metabolism were studied by superimposing an insulin infusion on a double infusion of $\left[{ }^{14} \mathrm{C}\right]$ glucose and $\left[{ }^{3} \mathrm{H}\right]-$ palmitate. In similar experiments with sheep (West \& Passey, 1967) an effect on plasma FFA metabolism could be demonstrated before blood glucose levels showed a significant decline, but in the pig blood glucose levels were almost as responsive as plasma FFA levels to insulin administration, in spite of the differences in their respective pool sizes. The initial rapid decline in plasma FFA, and the equally rapid rise in sra indicated reduced FFA mobilization, an effect eventually reversed by the sympatho-adrenal response to lowered blood glucose levels. The fall in blood glucose concentration was probably due to an increased uptake of glucose, accompanied by an increased volume of distribution (Steele, I966). The response of the pig to glucose load and to insulin suggested that the control of glucose and fat metabolism in pigs is similar to that in other species.

The glucose entry rate determined by isotope dilution represents the sum of all the routes which contribute glucose to the total body pool, and the nutritional significance of the index lies in the relative contributions of the alimentary tract, and of other tissues. The method of measurement of entry rate assumes that the various glucose pools in the whole animal are largely in equilibrium, but clearly in the fed pig (and presumably in other non-ruminants also) a substantial fraction of the glucose absorbed from the alimentary tract may be metabolized in the liver before equilibrating with the body glucose pool, largely represented by blood glucose. That is, a substantial fraction of the total glucose pool, namely the hepatic pool, may leave the system at a lower sra than that of the total pool. The net result is that the sra of blood glucose during the infusion of labelled glucose is higher than it would be if alimentary glucose escaped uptake by the liver. In the non-ruminant substantial glucose uptake by the liver in the fed animal is well established (Shoemaker, Yanof, Turk \& Wilson, I963). The influence of hepatic glucose metabolism on the measured glucose entry rate could be calculated only if values were available for the glucose concentrations in arterial and portal blood, for the magnitude of blood flow in the portal vein and in the hepatic artery, and for glucose uptake by the liver. In the present studies we have compared glucose entry rates measured in fed pigs with the calculated rate of glucose absorption from the alimentary tract. The latter calculation assumed that dietary starch, sucrose and lactose were completely hydrolysed, and that the glucose was absorbed into portal blood. No account was taken of possible losses due to the fermentation of glucose in the alimentary tract, or of glucose metabolism in the wall of the gut. The determined glucose entry rate, however, in all cases fell short of the rate of glucose absorption 
calculated over $24 \mathrm{~h}$, although entry rates were measured during the ro h feeding period when rates of glucose absorption might have exceeded the average calculated rate. Furthermore, gluconeogenesis from protein, and from the glycerol of fat, undoubtedly makes a further contribution to total glucose production. Clearly then, the glucose entry rate seriously underestimates the amount of glucose available to the tissues of the fed animal. These results strongly suggest that glucose entry rates determined in pigs fed diets which give rise to alimentary glucose may have little quantitative significance in relation to glucose metabolism. The results for glucose oxidation based on the comparison of the sra of glucose and $\mathrm{CO}_{2}$ in arterial blood must underestimate the extent of glucose oxidation if the hepatic oxidation of glucose represents a significant fraction of total glucose oxidation. These considerations in no way apply to the fasted animal, where there is little or no absorption of glucose from the alimentary tract. Glucose entry rates in this situation are largely the sum of glycogenolysis and of gluconeogenesis from protein, glycerol and lactate.

The use of the ratios of the sra of $\left[{ }^{14} \mathrm{C}\right]$ labelled substrate and ${ }^{14} \mathrm{CO}_{2}$ in arterial blood as a measure of substrate oxidation is a gross oversimplification of a most complex situation (see Steele, Altszuler, Wall, Dunn \& de Bodo, 1959; Annison et al. 1967). Insufficient results for the time-course of the output of ${ }^{14} \mathrm{CO}_{2}$ during the infusion of ${ }^{14} \mathrm{C}$-labelled substrates were obtained in the present work to permit a full mathematical analysis or the calculation of a terminal asymptotic value of the specific radioactivity of ${ }^{14} \mathrm{CO}_{2}$ (Annison et al. ${ }^{1967}$ ). The lack of the latter extrapolation, and the failure to take into account slowly equilibrating tissue pools of $\mathrm{CO}_{2}$ leads to underestimates of substrate oxidation: the transfer of ${ }^{14} \mathrm{C}$ into other substrates which contribute to oxidative metabolism acts in the opposite direction. We must stress that the use of uncorrected ${ }^{14} \mathrm{CO}_{2}$ values provides no more than rough estimates of the contribution of substrates to total oxidative metabolism.

The values for the contribution of glucose to $\mathrm{CO}_{2}$ production in fed $(3 \mathrm{r} \%)$ and fasted $(16 \%)$ pigs may be compared with the values of $2 \mathrm{I}$ and $9 \%$ respectively obtained in the chicken (Annison, Shrimpton \& West, I969). Comparable values for the fasted dog (Steele et al. 1959), rat (Depocas, 1962) and man (Young, Pelligra, Shapira, Adachi \& Skrettingland, I967) were $4 \mathrm{I}, \mathrm{I} 2$ and $30 \%$ respectively.

\section{REFERENCES}

Annison, E. F. (1964). In Metabolism and Physiological Significance of Lipids p. 289 [R. M. C. Dawson and D. N. Rhodes, editors]. London: John Wiley and Sons (Inc.).

Annison, E. F., Brown, R. E., Leng, R. A., Lindsay, D. B. \& West, C. E. (1967). Biochem. F. 104, 135. Annison, E. F. \& Lindsay, D. B. (1961). Biochem. F. 78, 777.

Annison, E. F., Lindsay, D. B. \& White, R. R. (1963). Biochem. F. 88, 243.

Annison, E. F., Shrimpton, D. H. \& West, C. E. (1969). In Energy Metabolism of Farm Animals p. 339 [K. L. Blaxter, J. Kielanowski and G. Thorbek, editors]. Newcastle: Oriel Press Ltd.

Annison, E. F. \& White, R. R. (I961). Biochem. F. 80, I62.

Annison, E. F. \& White, R. R. (I 962). Biochem. F. 84, 546.

Barcroft, J., McAnally, R. A. \& Phillipson, A. T. (1944). F. exp. Biol. 20, 120.

Barker, J. N. \& Britton, H. G. (1957). F. Physiol., Lond. 138, $3 P$.

Cunningham, H. M. (1967). F. Anim. Sci. 26, 1332.

Cunningham, H. M. \& Friend, D. W. (1965). F. Anim. Sci. 24, 41.

Depocas, F. (1962). Am. F. Physiol. 202, 1015.

Elsden, S. R., Hitchcock, M. W. S., Marshall, R. A. \& Phillipson, A. T. (1945-6). F. exp. Biol. 22, I91 . 
Eveleth, D. F. \& Eveleth, M. W. (1935). F. biol. Chem. III, 753 .

Folch, J., Lees, M. \& Stanley, G. H. S. (1957). F. biol. Chem. 226, 497.

Friend, D. W., Cunningham, H. M. \& Nicholson, J. W. G. (1963). Can. F. Anim. Sci. 43, I74.

Friend, D. W., Nicholson, J. W. G. \& Cunningham, H. M. (I964). Can. F. Anim. Sci. 44, 303.

Gutte, J. O., Kleiber, M., Raggi, F. R. \& Black, A. L. (196r). Z. Tierphysiol. Tierernähr. Futtermittelk. 16, 171 .

Hanawalt, V. M., Link, R. P. \& Sampson, J. (1947). Proc. Soc. exp. Biol. Med. 65, 4 I.

Huggett, A. St G. \& Nixon, D. A. (1957). Biochem. F. 66, $12 P$.

Jones, G. B. (1965). Analyt. Biochem. 12, 249.

Laurell, S. (1957). Acta physiol. scand. 4I, I 58.

Linzell, J. L., Mepham, T. B., Annison, E. F. \& West, C. E. (r969). Br. F. Nutr. 23, 319.

Sampson, J. \& Graham, R. (1943). F. Am. vet. med. Ass. 102, 176.

Shoemaker, W. C., Yanof, H. M., Turk, L. N. \& Wilson, T. H. (1963). Gastroenterology 44, 654 .

Steele, R. (1966). Ergebn. Physiol. 57, 91.

Steele, R., Altszuler, N., Wall, J. S., Dunn, A. \& de Bodo, R. C. (1959). Am. F. Physiol. 196, 22 I.

West, C. E. \& Passey, R. F. (1967). Biochem. Y. 102, 58.

West, C. E. \& Rowbotham, T. R. (1967). F. Chromat. 30, 62.

Young, D. R., Pelligra, R., Shapira, J., Adachi, R. R. \& Skrettingland, K. (1967). F. appl. Physiol. 23, 734 . 